\title{
Occurrence of ochratoxin A in black pepper, coriander, ginger and turmeric in India
}

K. Thirumala-Devi $\uparrow$, M. A. Mayo $\neq$, Gopal Reddy $\S$, K. E. Emmanuel $\uparrow$, Yvan Larondelle and D. V. R. Reddy $\dagger^{\dagger *}$

$\uparrow$ International Crops Research Institute for the Semi-Arid Tropics, Patancheru, Andhra Pradesh 502 324, India; $\$$ Scottish Crop Research Institute, Invergowrie, Dundee, DD2 5DA, UK; § Osmania University, Hyderabad, Andhra Pradesh 500 007, India; $\uparrow$ Unité de Biochimie de la Nutrition, Faculté des Sciences Agronomiques, Université catholique de Louvain, Place Croix du Sud 2 Bte 3, B1348 Louvain-la-Neuve, Belgium

(Received 17 July 2000; revised 14 January 2001; accepted 18 January 2001)

Ochratoxin A (OA) contamination of black pepper, coriander seeds, powdered ginger and turmeric powder was estimated using indirect competitive ELISA. Samples ( $1 \mathrm{~g}$ ) were extracted with $0.5 \%$ potassium chloride ( $\mathrm{KCl})$ in $70 \%$ methanol $(5 \mathrm{ml})$ and diluted subsequently to give two-fold to ten-fold step-wise dilutions in phosphate-buffered saline containing $0.05 \%$ Tween 20 and $0.2 \%$ bovine serum albumin (PBS-T BSA). For extracts from the spices analysed, ELISA estimates of $O A$ concentrations were compared with those made by HPLC. All estimates were within 1-2 standard deviation of the ELISA values. More than $90 \%$ of $O A$ added to spice samples was recovered from samples containing between 5 and $100 \mu \mathrm{g} / \mathrm{kg} O A$. Extracts of $O A$-free spice samples contained substances that interfered with ELISA, presumably because of non-specific reactions. This effect was avoided by preparing all the test solutions in extracts of $O A$-free spice samples. In 126 samples obtained from retail shops, $O A$ was found to exceed $10 \mu_{\mathrm{g}} / \mathrm{kg}$ in 14 (in the range of $15-69 \mu \mathrm{g} / \mathrm{kg}$ ) of 26 black pepper samples, 20 (in the range of $10-51 \mu \mathrm{g} / \mathrm{kg}$ ) of 50 coriander samples, two $\left(23 \mu_{\mathrm{g}} / \mathrm{kg}\right.$ and $\left.80 \mu_{\mathrm{g}} / \mathrm{kg}\right)$ of 25 ginger samples and nine (in the range of $11-102 \mu \mathrm{g} / \mathrm{kg}$ ) of 25 turmeric samples. This is the first record in India of the occurrence of $O A$ in what are some of the most widely used spices in Indian cooking.

* To whom correspondence should be addressed. e-mail: d.reddy@, cgiar.org
Keywords : ochratoxin A, indirect competitive ELISA, HPLC, black pepper, coriander, ginger, turmeric

\section{Introduction}

Ochratoxins are a group of toxic secondary metabolites produced by certain fungi in the genera Aspergillus and Penicillium (Steyn 1971, Applegate and Chipley 1973, Chu 1974, Harwig 1974). Among them, ochratoxin A is the most toxic. It has been shown to be nephrotoxic, hepatotoxic, teratogenic, carcinogenic, mutagenic and to be an immunosuppressive agent (Kuiper-Goodman and Scott 1989). Of greatest concern for human health is its implication in an irreversible and fatal kidney disease referred to as 'Balkan Endemic Nephropathy' (Krogh 1974). OA has been found to occur in foods of plant origin, in edible animal tissues, and in human milk, blood sera and tissues (Creppy et al. 1995).

OA has been detected in diverse food and feed commodities (Veldman et al. 1992, Oyelami et al. 1996, Zimmerli and Dick 1996), including spices. Spices found by HPLC to contain relatively high $(>5 \mu \mathrm{g} / \mathrm{kg})$ levels of $\mathrm{OA}$ were Chinese red pepper (Akiyama et al. 1998) and paprika and nutmeg (Vrabcheva et al. 1998). The moulds isolated from spices are predominantly Aspergillus and Penicillium species (Flannigan and Hui 1976) and these are implicated in the production of several mycotoxins.

Spices and condiments are extensively used in Oriental and Indian cooking. The only record of ochratoxin A contamination in spices from India is its detection by ELISA in chillies (Thirumala-Devi et al. 2000). In this paper, we report the occurrence of $\mathrm{OA}$ in many samples of four of the most commonly used spices in India, namely black pepper, coriander, ginger and turmeric by both ELISA and HPLC methods. 


\section{Materials and methods}

\section{Materials}

Ochratoxin A, ochratoxin A-BSA conjugate, goat anti-rabbit IgG-ALP conjugate, $p$-nitrophenyl phosphate, and bovine serum albumin (BSA), were all purchased from Sigma Chemical Co., St Louis, USA. Microtitre plates (Maxi-sorp F96) were obtained from Nunc (Nalge Nunc International, Denmark) and immunoaffinity columns from Vicam, Watertown, MA, USA. Chloroform, acid acetic and orthophosphoric acid were analytical grade; acetonitrile, methanol and toluene were HPLC grade. All other chemicals were reagent grade or chemically pure.

\section{Collection of samples and preparation for ELISA}

Black pepper (26 samples), coriander (50 samples), ginger (25 samples), and turmeric ( 25 samples) were purchased from retail shops in $200 \mathrm{~g}$ quantities. Black pepper and coriander were purchased as seeds and turmeric and ginger were bought as powders. Black pepper and coriander were ground to a fine powder in a Waring blender and ginger and turmeric powders were used without any further grinding. Samples of $200 \mathrm{~g}$ were thoroughly mixed and three $15 \mathrm{~g}$ subsamples were taken. Each sub-sample was extracted with $75 \mathrm{ml}$ of a mixture of $0.5 \% \mathrm{KCl}$ in $70 \%$ methanol by blending in a Waring blender. Extraction was followed by shaking for $30 \mathrm{~min}$ and filtration through Whatman No. 41 filter paper. The filtrate was diluted two- to ten-fold in phosphate-buffered saline containing $0.05 \%$ Tween 20 and $0.2 \%$ bovine serum albumin (PBS-T BSA) prior to ELISA.

\section{Antibodies}

OA polyclonal antibodies were those described by Thirumala-Devi et al. (2000). Antibodies were highly specific for OA and did not cross react with ochratoxin $\mathrm{B}$, coumarin, 4-hydroxy coumarin or L-phenylalanine.
Indirect competitive ELISA procedure for processing the various spice samples

An indirect ELISA procedure similar to that reported for aflatoxins (Devi et al. 1999) and ochratoxin A (Thirumala-Devi et al. 2000) was used. Microtitre plate wells were coated with $1 \mu \mathrm{g} / \mathrm{ml}$ of OA-BSA in $0.2 \mathrm{M}$ sodium carbonate buffer, $\mathrm{pH} 9.6(150 \mu \mathrm{l} /$ well $)$ overnight at $4^{\circ} \mathrm{C}$. Subsequent steps were at $37^{\circ} \mathrm{C}$ for $1 \mathrm{~h}$. Antiserum was diluted in PBS-T BSA, held for $45 \mathrm{~min}$ at $37^{\circ} \mathrm{C}$ and added in $50 \mu \mathrm{l}$ volumes to $100 \mu \mathrm{l}$ of OA standards ranging from $100 \mathrm{ng} / \mathrm{ml}$ to $100 \mathrm{pg} / \mathrm{ml}$, prepared in a diluted extract from spices that did not contain OA (verified by HPLC). Spice samples were extracted with aqueous methanol- $\mathrm{KCl}$ as described above, filtered and used at a 1:10 dilution in PBS-T BSA, except for ginger which was diluted to 1:8. One hundred $\mu \mathrm{l}$ of each sample were added to wells containing $50 \mu \mathrm{l}$ of antiserum diluted to 1:100000. Goat antirabbit immunoglobulins (GAR IgG) conjugated to alkaline phosphatase were used at a 1:1000 dilution to detect rabbit antibodies attached to OABSA. $p$-nitrophenyl phosphate was used as a substrate at $1 \mathrm{mg} / \mathrm{ml}$. Absorbance was recorded at $405 \mathrm{~nm}$ $\left(A_{405}\right)$ with an ELISA plate reader (Titertek Multiskan, Lab Systems, Finland) after incubation at room temperature for $1 \mathrm{~h}$.

Standard curves were obtained by plotting $\log _{10}$ values of OA concentration against optical density at $A_{405}$. The concentrations of $\mathrm{OA}$ in samples were determined from the standard curves and expressed in $\mu \mathrm{g} / \mathrm{kg}$ using the formula: OA concentration $(\mathrm{ng} / \mathrm{ml})$ in sample extract $\times$ dilution with buffer $\times$ extraction solvent volume used $(\mathrm{ml})$ /sample weight (g). In order to test the recovery of OA, $15 \mathrm{~g}$ spices were mixed with pure $\mathrm{OA}$ to give concentrations ranging from 1 to $100 \mu \mathrm{g} / \mathrm{kg}$. Spiked samples were extracted and assayed as for unknown samples.

\section{Determination of $O A$ by $H P L C$}

Ochratoxin A was extracted by using an adaptation of the extraction procedure of the Technical Committee of European Committee for Standardization (CEN/TC 275 1998). Spice powder samples $(50 \mathrm{~g})$ were transferred into a $500 \mathrm{ml}$ PTFE (polytetrafluoro ethylene) container mixed with $200 \mathrm{ml}$ chloroform and $20 \mathrm{ml} 0.1 \mathrm{M}$ orthophosphoric acid. This mixture was triturated for 3 min with the 
Table 1. Recovery of OA from artificially contaminated spice samples as determined by HPLC.

\begin{tabular}{ccc}
$\begin{array}{l}\text { Concentration of OA } \\
\text { used for spiking }(\mu \mathrm{g} / \mathrm{kg})\end{array}$ & $\begin{array}{c}\text { Concentration of OA } \\
\text { estimated }(\mu \mathrm{g} / \mathrm{kg})^{\mathrm{a}}\end{array}$ & $\begin{array}{c}\text { Percent recoveries of } \\
\text { OA from spiked samples }\end{array}$ \\
\hline 0.4 & $0.36 \pm 0.01$ & $90.1 \pm 0.03$ \\
1.0 & $0.89 \pm 0.01$ & $88.9 \pm 0.01$ \\
2.4 & $2.08 \pm 0.03$ & $86.5 \pm 0.01$ \\
6.0 & $5.28 \pm 0.07$ & $87.9 \pm 0.01$ \\
10.0 & $9.05 \pm 0.28$ & $90.5 \pm 0.03$ \\
\hline
\end{tabular}

\footnotetext{
${ }^{\mathrm{a}}$ Samples were spiked with a known concentration of OA and assayed. Data represent mean of three replications $\pm \mathrm{SD}$.

${ }^{\mathrm{b}}$ Determined by the formula, detected OA $(\mu \mathrm{g} / \mathrm{kg})$ divided by the concentration of OA used for spiking and multiplied by 100 . Values are means \pm SD.
}

Ultra-Turrax CAT $\times 620$ (Staufen, Germany) fitted with a T17-V shaft at $13500 \mathrm{rpm}$ to produce a slurry. After centrifugation for $10 \mathrm{~min}$ under $820 \mathrm{~g}$ at $5-10^{\circ} \mathrm{C}$, the chloroform phase was transferred to a $500 \mathrm{ml}$ beaker. The remaining part was extracted again with $200 \mathrm{ml}$ chloroform and $20 \mathrm{ml}$ of $0.1 \mathrm{M}$ orthophosphoric acid. The combined chloroform phases ( $c a 350 \mathrm{ml}$ ) were evaporated to dryness by rotary evaporation at $30-40^{\circ} \mathrm{C}$. The residue was dissolved in $100 \mathrm{ml}$ of $0.5 \mathrm{M}$ $\mathrm{NaHCO}_{3}$ and transferred to a $120 \mathrm{ml}$ PTFE container. After $10 \mathrm{~min}$ centrifugation at $820 \mathrm{~g}$ at $5-10^{\circ} \mathrm{C}$, $20 \mathrm{ml}$ of sample was passed through an Ochratest ${ }^{\mathrm{TM}}$ immunoaffinity column (Vicam, Watertown, MA, USA) at about $1-2 \mathrm{ml} / \mathrm{min}$. Before loading the extract, the Ochratest ${ }^{\mathrm{TM}}$ column was conditioned with PBS, pH $7.4(20 \mathrm{ml})$. Twenty $\mathrm{ml}$ of de-ionized water was used to wash the loaded immunoaffinity column and OA was then eluted with $2 \mathrm{ml}$ methanol and $2 \mathrm{ml}$ de-ionized water. Atmospheric air ( $c a 20 \mathrm{ml}$ ) was passed through the column to collect all the eluate. A $1 \mathrm{ml}$ sample of the eluate was then filtered through a $0.45 \mu \mathrm{m}$ microfilter (Millex ${ }^{\mathbf{R}}-\mathrm{HV}$ ) for HPLC analysis. For HPLC, $50 \mu \mathrm{l}$ samples were injected by full loop injection. The chromatographic system consisted of a Perkin-Elmer LC049 isocratic pump (Norwalk, CT, USA) equipped with a Rheodyne model 7125 NS injection valve $(50 \mu \mathrm{l})$ (Rheodyne, Cotati, CA, USA), an RF-551 fluorescence spectrophotometer detector (Shimadzu, Kyoto, Japan) equipped with a $150 \mathrm{~W}$ xenon lamp $\left(\lambda_{\text {excitation }}=332 \mathrm{~nm}\right.$ and $\left(\lambda_{\text {emission }}=\right.$ $462 \mathrm{~nm}$ ) and a Spectra-Physics SP4290 chromato-integrator (San José, CA, USA). The analytical column was an Hypersil ${ }^{\mathrm{TM}}$ BDS reversed-phase $\mathrm{C}_{18}$ $(150 \times 4.0 \mathrm{mmi}$.d., $3 \mu \mathrm{m}$ particle size) (Tracer Analytical, Barcelona, Spain). The column was left at ambient temperature. The mobile phase was acetonitrile-water-acetic acid (45:54:1 v/v/v) eluted at a flow rate of $1.0 \mathrm{ml} / \mathrm{min}$. OA was assayed by measuring peak height at the ochratoxin A retention time and comparing it with the relevant calibration curve (five points, in the range $1-5 \mathrm{ng}$ of ochratoxin $\mathrm{A} / \mathrm{ml}$, $\left.r^{2}=0.9992\right)$. Standard solutions for the calibration curve were prepared in the mobile phase from a stock solution containing $20 \mu \mathrm{g} / \mathrm{ml}$ of OA in toluene-acetic acid (99:1).

Within the tested range of spiking samples $(0.4-10 \mu \mathrm{g}$ $\mathrm{OA} / \mathrm{kg}$ ), the procedure showed good precision $(\mathrm{RSD}=3.1 \%)$ and accuracy with an overall recovery of $89 \pm 1.6 \%$ (table 1). The detection limit of ochratoxin A was $10 \mathrm{ppt}$ (based on the ratio signal/ noise $=3 / 1$ ) and the quantitation limit was $35 \mathrm{ppt}$ (based on the ratio signal $/$ noise $=10 / 1$ ).

\section{Results and discussion}

\section{Comparison of estimates of $O A$ concentration by ELISA and HPLC}

The OA contents of samples spiked with pure OA were estimated by ELISA and HPLC. The results show good correspondence (table 2). HPLC estimates were within $2 \mathrm{SD}$ of ELISA estimates, although always less.

\section{Effect of extracts from various spices in ELISA}

The ELISA procedure reported for OA estimation in chillies (Thirumala-Devi et al. 2000) gave a non- 
Table 2. Determination of $O A$ in selected spice samples by ELISA and HPLC.

\begin{tabular}{lrc}
\hline & \multicolumn{2}{c}{ OA contamination $^{-}$} \\
\cline { 2 - 3 } Sample type & \multicolumn{1}{c}{ ELISA $^{\mathrm{a}}$} & HPLC $^{\mathrm{a}}$ \\
\hline Black pepper & $4.2 \pm 1.2$ & $\mathrm{ND}$ \\
Black pepper & $103.2 \pm 5.1$ & 98.3 \\
Coriander & $8.3 \pm 0.9$ & 7.8 \\
Coriander & $59.0 \pm 2.4$ & 53.0 \\
Ginger & $25.3 \pm 0.8$ & 23.3 \\
Ginger & $77.8 \pm 4.3$ & 71.3 \\
Turmeric & $32.4 \pm 1.9$ & 29.1 \\
Turmeric & $54.0 \pm 3.6$ & 47.4 \\
\hline
\end{tabular}

${ }^{\mathrm{a}}$ ELISA values are means of three estimates $\pm \mathrm{SD}$; HPLC values are for single estimates.

specific reaction, presumably due to interference by substances present in the spice extracts. To confirm that interference in ELISA was due to substances in spice samples, we compared OA standards prepared in PBS-T BSA with those prepared in spice extract shown by ELISA to contain the equivalent of less than $10 \mu \mathrm{g} / \mathrm{kg}$ OA. Curves were found to be influenced by substances present in different spice extracts (figure 1). As a result, it was essential to prepare the standard solutions of OA in extracts of spices. Chillies have been shown to contain substances that bind to aflatoxins (Shantha 1999) and also that interfere in the estimation by indirect ELISA of OA (ThirumalaDevi et al. 2000). Thus, toxin standards were prepared in spice extracts shown to be substantially free of OA.

\section{Recovery of $O A$ from spiked spice samples}

To confirm that the extraction procedures were effective, pure OA was added to powdered spice samples and extracted in $70 \%$ methanol- $\mathrm{KCl}$. Recoveries from samples of black pepper, coriander and turmeric samples estimated by ELISA were greater than $90 \%$ (table 3). However, recovery from ginger samples was $>90 \%$ only when extracts were diluted eight-fold.

\section{Analysis of spice samples collected from retail shops}

The results of OA analysis of spices collected from retail shops are shown in table 4 . Three replicates

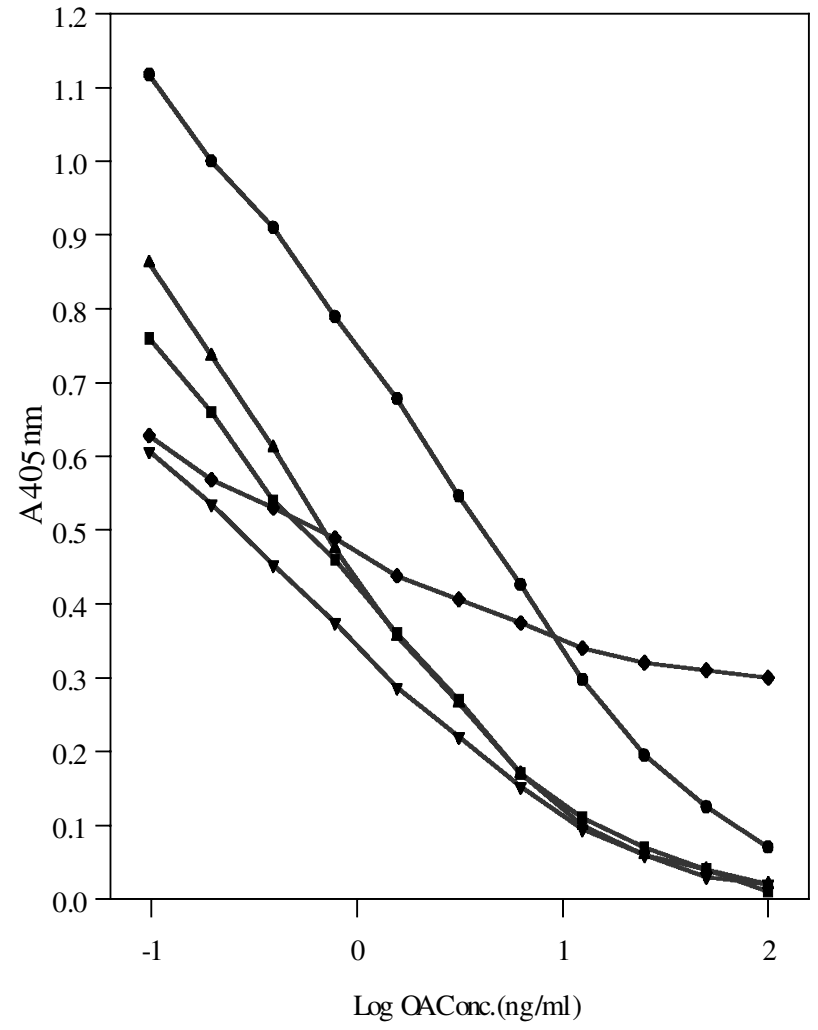

Figure 1. Effect of extracts of spices on the standard curve of $O A$ by indirect competitive ELISA. OA standard curves prepared in $7 \%$ methanol $(\bullet)$, black pepper $(\bullet)$, coriander ( $\mathbf{\Delta})$, ginger ( $\mathbf{\square})$, and turmeric ( $\mathbf{\nabla})$ extracts.

of 126 samples of black pepper, coriander, ginger and turmeric were measured. The results showed that 45 samples contained more than $10 \mu \mathrm{g} / \mathrm{kg}$ OA in amounts that ranged up to $110 \mu \mathrm{g} / \mathrm{kg}$ (table 3).

OA contamination occurred at higher levels in black pepper, turmeric and coriander than in ginger. High levels of OA $(110 \mu \mathrm{g} / \mathrm{kg})$ were detected in turmeric, which is one of the most widely used spices in Indian cooking.

The production of $\mathrm{OA}$ and the growth of the fungi responsible are dependent upon factors such as temperature, humidity, handling during harvesting and conditions during storage. The majority of spices are produced in countries with tropical climates, which favour growth of the fungi. Unfortunately, methods that would be suitable for particular spices have not been developed. We also presume that lack of sufficient surveillance data on the occurrence of $\mathrm{OA}$ in spices in India can be attributed to the 
Table 3. Recovery of OA from artificially contaminated spice samples as determined by ELISA.

\begin{tabular}{lccc}
\hline No. & $\begin{array}{c}\text { Concentration of OA } \\
\text { used for spiking }(\mu \mathrm{g} / \mathrm{kg})\end{array}$ & $\begin{array}{c}\text { Concentration of OA } \\
\text { estimated }(\mu \mathrm{g} / \mathrm{kg})^{\mathrm{a}}\end{array}$ & $\begin{array}{c}\text { Percent recoveries of } \\
\text { OA in spiked samples }\end{array}$ \\
\hline Black pepper & & & \\
1 & 5 & $4.80 \pm 0.39$ & $96.0 \pm 8.1$ \\
2 & 10 & $9.60 \pm 0.82$ & $96.0 \pm 8.6$ \\
3 & 50 & $49.2 \pm 0.88$ & $103 \pm 4.0$ \\
4 & 100 & $104 \pm 4.08$ & \\
Coriander & & & $118.0 \pm 9.7$ \\
1 & 5 & $5.90 \pm 0.57$ & $105.3 \pm 7.8$ \\
2 & 10 & $10.5 \pm 0.82$ & $105 \pm 4.0$ \\
3 & 50 & $52.5 \pm 2.1$ & $108 \pm 7.4$ \\
4 & 100 & $108 \pm 7.9$ & $94.7 \pm 6.2$ \\
Ginger & & & $93.0 \pm 7.8$ \\
1 & 5 & $4.73 \pm 0.29$ & $99.1 \pm 1.5$ \\
2 & 10 & $9.30 \pm 0.73$ & $104 \pm 5.3$ \\
3 & 50 & $49.5 \pm 0.72$ & \\
4 & 100 & $104 \pm 5.5$ & $99.3 \pm 1.0$ \\
Turmeric & & & $100 \pm 0.82$ \\
1 & 5 & $4.97 \pm 0.05$ & $106 \pm 5.9$ \\
2 & 10 & $10.0 \pm 0.08$ & $98.7 \pm 1.0$ \\
\hline
\end{tabular}

${ }^{a}$ Each sample was spiked with a known concentration of $\mathrm{OA}$, extracted in $70 \%$ methanol and assayed. Data represent mean of three replications \pm SD.

${ }^{\mathrm{b}}$ Determined by the formula, detected OA $(\mu \mathrm{g} / \mathrm{kg})$ divided by the concentration of OA used for spiking and multiplied by 100 . Values are Means \pm SD.

Table 4. Incidence and range of $O A$ in selected spice samples as determined by indirect competitive ELISA.

\begin{tabular}{|c|c|c|c|c|c|c|}
\hline \multirow[b]{2}{*}{ Sample type ${ }^{a}$} & \multicolumn{2}{|c|}{ OA contamination } & \multicolumn{4}{|c|}{$\begin{array}{l}\text { No. of samples with OA } \\
(\mu \mathrm{g} / \mathrm{kg}) \text { contents in the } \\
\text { ranges of }\end{array}$} \\
\hline & Incidence & $\%$ contamination & 10-29 & $30-49$ & $50-100$ & 110 \\
\hline Black pepper & $14 / 26$ & 54 & 8 & 5 & 1 & 0 \\
\hline Coriander & $20 / 50$ & 40 & 16 & 3 & 1 & 0 \\
\hline Ginger & $2 / 25$ & 8 & 1 & 0 & 1 & 0 \\
\hline Turmeric & $9 / 25$ & 36 & 3 & 2 & 3 & 1 \\
\hline
\end{tabular}

${ }^{\mathrm{a}}$ See text for details.

non-availability of inexpensive diagnostic tools. The present study clearly showed that four important spices can harbour OA at levels beyond those permitted by public health authorities. Our results emphasize the need for surveillance of OA contamination in spices and suggest that strategies should be developed that can lead to contamination being minimized.

\section{Acknowledgements}

This document is an output from a project (R7083) funded by the UK Department for International Development (DFID) for the benefit of developing countries. The views expressed are not necessarily those of DFID. KT-D and DVRR are supported by 
ICRISAT. MAM acknowledges financial support from the Scottish Executive Rural Affairs Department.

\section{References}

Akiyama, H., Kikuchi, Y., Chen, D., Goda, Y., Takatori, K., ICHINOE, M., and Toyoda, M., 1998, A rapid analytical method of ochratoxin A (OTA) in foods and natural contamination of OTA in red pepper. Revue de Médecine Vétérinaire. 149, 502.

Applegate, K. L., and Chipley, J. R., 1973, Ochratoxins. Advances in Applied Microbiolog y, 16, 97-109.

CEN/TC 275, 1998, Foodstuffs-Determination of ochratoxin A in cereals and cereal products-part 2: High performance liquid chromatographic method with bicarbonate clean up (ISO FDIS 15141-2:1998), Brussels, Belgium, 12 pp.

Chu, F. S., 1974, Studies on ochratoxins. Critical Reviews in Toxicology, 2, 499-524

Creppy, E. E., Baudrimont, I., and Betbeder A. M., 1995, Prevention of nephrotoxicity of ochratoxin A, a food contaminant. Toxicology Letters, 82-83, 869-877.

Devi, K. T., Mayo, M. A., Reddy, K. L. N., Delfosse, P., Gopal RedDy, RedDy, S. V., and RedDy, D. V. R., 1999, Production and characterization of monoclonal antibodies for aflatoxin $\mathrm{B}_{1}$. Letters in Applied Microbiology, 29, 284-288.

Flanningan, B., and Hui, S. C., 1976, The occurrence of aflatoxinproducing strains of Aspergillus flavus in the mould floras of ground spices. Journal of Applied Bacteriology, 41, 411-418.
Harwig, J., 1974, Ochratoxin A and related metabolites. Mycotoxins, edited by I. F. H. Purchase (Amsterdam: Elsevier Scientific Publishing Co.) pp. 345-367.

Krogh, P., Hald, B., Englund, P., Rutqvist, L., and Swahn, O., 1974, Contamination of Swedish cereals with ochratoxin A. Acta Pathologica et Microbiologica Scandinavia, 32, 301-302.

Kuiper-Goodman, T., and ScotT, P. M., 1989, Risk assessment of the mycotoxin ochratoxin A. Biomedical and Environmental Sciences, 2, 179-248.

Oyelami, O. A., Maxwell, S. M., and Adeoba, E., 1996, Aflatoxins and ochratoxin A in the weaning food of Nigerian children. Annals of Tropical Pediatrics, 16, 137-140.

Shantha, T., 1999, Critical evaluation of methods available for the estimation of aflatoxin $\mathrm{B}_{1}$ in chilli powder. Journal of Food Science and Technology, 36, 163-165.

Steyn, P. S., 1971, Ochratoxin and other dihydroisocoumarins. Microbial toxins, Vol. 6, edited by A. Ciegler, S. Kadis, and S. J. Ajl (New York: Academic Press), pp. 179-205.

Thirumala-Devi, K., Mayo, M. A., Delfosse, P., Gopal Reddy, Reddy, S. V., and RedDy, D. V. R., 2000, Production of polyclonal antibodies for ochratoxin A and its detection in chillies by ELISA. Journal of Agricultural and Food Chemistry, 48, 5079-5082.

Veldman, A., Borgreve, G. J., Mulders, E. J., and Van de LAGEMAAT, D., 1992, Occurrence of the mycotoxins ochratoxin A, zearalenone and deoxynivalenol in feed components. Food Additives and Contaminants, 9, 647-655.

Vrabcheva, T., Gareis, M., Bresch, H., Bodechtel, C., Engel, G., Majerus, P., Rosner, H., and WolfF, J., 1998, Occurrence of ochratoxin A and $\mathrm{B}$ in spices and herbs. Revue de Médecine Vétérinaire, 149, 553.

Zimmerli, B., and Dick, R., 1996, Ochratoxin A in table wine and grape-juice: occurrence and risk assessment. Food Additives and Contaminants, 13, 655-668. 